Bangl. J. Vet. Med. (2006). 4 (2): 73-77

\title{
DETECTION OF AVIAN ROTAVIRUS-LIKE VIRUS IN BROILER CHICKENS IN BANGLADESH
}

\author{
M. S. Ahmed ${ }^{* 1}$ and M. U. Ahmed \\ Department of Medicine, Faculty of Veterinary Science, Bangladesh Agricultural University, \\ Mymensingh-2202, Bangladesh
}

\begin{abstract}
The presence of rotavirus infection in broiler chickens (1-2 weeks old) was studied. A total of 232 faecal specimens were collected during the period from July to September 2004 and examined by polyacrylamide gel electrophoresis and silver staining (PAGE-ss) technique for the presence of rotavirus dsRNA in the Department of Medicine, Faculty of Veterinary Science, Bangladesh Agricultural University, Mymensingh, Bangladesh. The total prevalence of rotavirus infection in broiler chickens was in Gazipur 2.43\% and 0\% in Mymensingh. In the two specimens positive for avian rotavirus (ARV), identical and peculiar RNA patterns were observed and were not similar to those for groups A, D, or F, but partially similar to that of group $\mathrm{G}$ rotavirus, suggesting that these viruses may belong to novel rotavirus group. Additional studies on more numbers of strains obtained from different flocks will be necessary to substantiate the notable observation.
\end{abstract}

Key words: Avian rotavirus-like virus, broiler chickens

\section{INTRODUCTION}

Rotavirus is a major cause of gastroenteritis in infants and young children worldwide and also in wide variety of mammalian and avian species (Estes et al., 1983). Rotavirus has 11 segments of double stranded RNA (dsRNA) as genome. Rotavirus in birds (avian rotavirus) known so far belongs to groups A, D, F and G (Saif, 1989). Prevalence of avian rotavirus has never been studied in Bangladesh. Hence, the present study was designed to detect rotavirus associated diarrhoea in broiler chickens in 1 to 2 weeks of age as well as to determine the prevalence of rotavirus infection in broiler chickens in Mymensingh and Gazipur districts of Bangladesh.

\section{MATERIALS AND METHODS}

The presence of rotavirus in diarrhoeal specimens from broiler chickens (1-2 weeks old age) was studied. A total of 232 faecal specimens were collected during the period from July to September 2004. The collected samples were processed with phosphate buffer solution in the Department of Medicine, Faculty of Veterinary Science, Bangladesh Agricultural University, Mymensingh-2202, Bangladesh. For the RNA extraction, $300 \mu \mathrm{l}$ faecal suspension was mixed with $100 \mu \mathrm{l}$ of disrupting solution and vortexed. Then, $300 \mu \mathrm{l}$ of saturated phenol was added and vortexed, $300 \mu \mathrm{l}$ of chloroform was added. After stirring, the mixture was centrifuged at 14000 $\mathrm{rpm}$ in microcentrifuge for 5 minutes and precipitated with $\mathrm{NaCl}$ and ethanol at $-20^{\circ} \mathrm{C}$. After centrifugation, the pellet was dried and suspended with $15 \mu \mathrm{l}$ of $0.5 \%$ bromophenol blue (BPB) and used for polyacrylamide gel electrophoresis at $20 \mathrm{~mA}$ for 16 hours. After electrophoresis, the gels were washed thrice in distilled water, and incubated in $5 \%$ silver nitrate solution for 1 hour on shaker. After washing with distilled water, the gels were put into the developing solution (75\% $\mathrm{NaOH}$ and $0.3 \%$ formaldehyde solution) with continuous shaking. The discrete bands of 11 segments dsRNA appeared in positive cases. The photograph of the RNA pattern was taken as a record.

Present address : ${ }^{1}$ Department of Medicine and Surgery, Barisal Government Veterinary College, Barisal.

*Corresponding author’s e-mail address : vetselim476@yahoo.comT 


\section{RESULTS AND DISCUSSION}

A total of 232 faecal specimens have been collected from broiler chickens (1-2 weeks of age) of different poultry farm in Mymensingh and Gazipur. The faecal specimens were examined for presence of rotavirus using polyacrylamide gel electrophoresis that revealed 2 (0.86\%) specimens had rotavirus infection. Rotavirus infection in broiler chickens (1-2 weeks) found in Gazipur and Mymensingh is shown in Table 1.

Table 1. Prevalence of rotavirus infection in broiler chickens (1 to 2 weeks of age) in Mymensingh and Gazipur districts

\begin{tabular}{|c|c|c|c|c|c|c|}
\hline Place & Name of farms & $\begin{array}{l}\text { Total Nr. } \\
\text { of samples }\end{array}$ & $\begin{array}{l}\text { Nr. of positive } \\
\text { sample }\end{array}$ & $\begin{array}{l}\text { Prevalence in } \\
\text { terms of farm }\end{array}$ & $\begin{array}{l}\text { Prevalence in } \\
\text { terms of place }\end{array}$ & $\begin{array}{l}\text { Overall } \\
\text { prevalence }\end{array}$ \\
\hline Gazipur & $\begin{array}{l}\text { CP Poultry Farm } \\
\text { Ma Poultry Farm }\end{array}$ & $\begin{array}{l}52 \\
30\end{array}$ & $\begin{array}{l}0 \\
2\end{array}$ & $\begin{array}{l}0.00 \\
6.67\end{array}$ & $2.43 \%$ & \\
\hline Mymensingh & $\begin{array}{l}\text { Farm I } \\
\text { Farm II } \\
\text { Farm III }\end{array}$ & $\begin{array}{l}60 \\
44 \\
46\end{array}$ & $\begin{array}{l}0 \\
0 \\
0\end{array}$ & $\begin{array}{l}0.00 \\
0.00 \\
0.00\end{array}$ & $0.00 \%$ & $0.86 \%$ \\
\hline
\end{tabular}

The prevalence of rotavirus infection were 2.43\% in Gazipur and $0 \%$ in Mymensingh. To our knowledge it is the first detection of avian rotavirus-like virus in broiler chickens in Bangladesh. Although detection rate of avian rotavirus is low in clinical samples in Bangladesh, higher rate of rotavirus infection have been documented by McNulty et al. (1979) where $40 \%$ of chicken farms and $59 \%$ of bird on these farms in USA were rotavirus seropositive. Saif et al. (1985) reported that rotavirus detection rate $50 \%$ of farms sampled and 58\% of the flocks positive on these farms. McNulty et al. (1984) further reported that $70 \%$ of serum samples from broiler breeder from 14 farms in Ireland were seropositive for rotavirus-like virus. These result indicated that there is a possibility to have rotavirus infection in broiler chickens in Bangladesh. Despite the first report, our present study indicated the presence of avian rotavirus-like virus in broiler chickens. A further study is essential to confirm these findings. In this study 1-2 weeks of broiler chickens were selected for detection of rotavirus. Because, this age is the vulnerable age for rotavirus infection. McNulty et al., (1979 and 1981) isolated rotavirus from 6 day-old turkey and from broiler chicken with diarrhoea. Yason and Schat (1984) reported that rotavirus were isolated from groups of white Leghorn chickens less than 14 days old. Theil and Saif (1987) also reported that turkeys were often infected during the first week of life, whereas broiler chickens were not infected until later, may which correlate with our findings. There are a few reports on electrophoretic analysis of avian rotavirus (McNutly et al., 1980; and Saif et al., 1985). The results in these researches were based on the analysis of dsRNA from a small number of strains. The present study reports the analysis of dsRNAs from rotavirus isolated from 2 diarrhoeic chickens. This study demonstrated that genomes of avian rotavirus- like virus (AVRVLV) have almost similar electrophoretic mobility.

Figure 1 showed that comparision of electrophoretic mobility of avian rotavirus -like virus with human group A rotavirus (long and short pattern) and turkey rotavirus. In human rotaviruses two different electrophoretic patterns of dsRNA "Short" and "Long" based on the differences in the mobility of segments 10 and 11of their genome have been described (Espejo et al., 1977; Kalica et al., 1981 and Rodriguez et al., 1983). Human rotaviruses with genome that gave short electrophoretic patterns belong to subgroup I, and those with the long pattern belong to subgroup II (Espejo et al., 1977 and Rodger et al., 1981). In our experiment, we could not assign the RNA patterns of avian rotavirus -like virus as either short or long patterns, as those of human rotaviruses. In human rotavirus (long and short type) genome electropherotype migration pattern in the first size class segments 1 to 4 . Segments 5 and 6 migrate in the second size class, segments 7, 8 and 9 migrate in the third size class and segments 10 and 11 migrate in the fourth size class (Rodger et al., 1981). In turkey rotavirus, migration pattern of genome electropherotype in the first size class segment 1 to 5 , segments 6 and 7 migrates in the second size class as close spaced coupled, segments 8 and 9 migrates in the third size class and segments 10 and 11 migrates in the fourth size class (Theil et al., 1986). 
In the study avian rotavirus- like virus genome electropherotype revealed two segments migration pattern in the first size class segment 1 and 2 and segments 3 and 4 closely. The segment 5 migrated separately in the second size class, which coincide the findings made by Hancock et al. (1983). Whereas in case of group A rotavirus segment 5 and 6 migrates in the second size class and in turkey rotavirus segment 6 and 7 migrates in the second size class. Similarly segment 6 and 7 and 8 and 9 migrated together in the second size class. The migration of segment 10 and 11 in the fourth size class of avian RVLV genome electropherotype migrated as close spaced couplet which correlates with the observation made by Todd et al. (1980). The segments of the avian RVLV genome electropherotypes migrated sufficiently apart so that all 11 segments could be resolved. The avian rotavirus- like virus electropherotype is having only one segment (segment 5 ) in the second size class migrated widely.

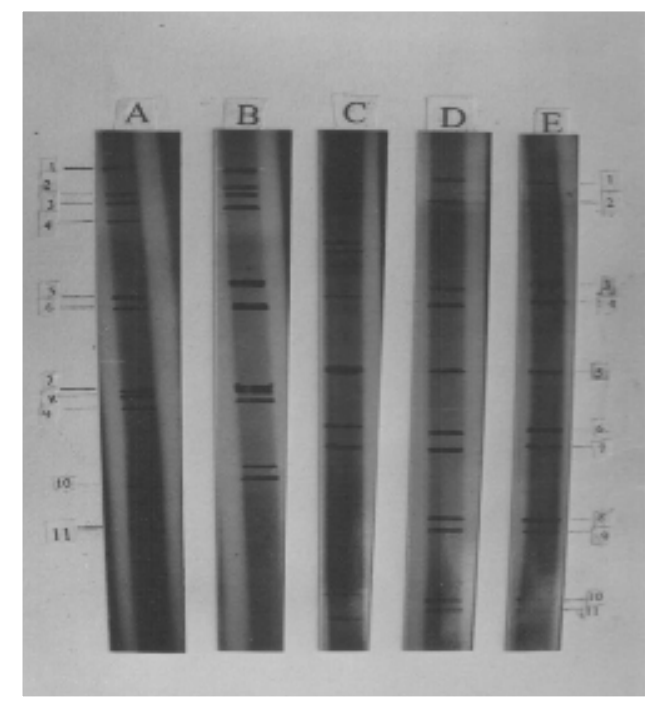

Fig. 1. Comparisons of electrophoretic pattern of human rotavirus, turkey rotavirus and avian rotavirus like-virus electropherotypes in lane ' $A$ ' strain to ' $E$ ' strain [From the extreme left 'A' strain (long type human rotavirus), 'B' strain (short type human rotavirus), ' $\mathrm{C}$ ' strain (Turkey rotavirus), 'D' strain and ' $E$ ' strain (avian rotavirus like virus)].

Figure 2 showed that co- electrophoresis of the positive strain was performed to observe the variation of migration of RNA segments. Co- electrophoresis of the ds RNA preparations obtained from the two chickens infected with rotavirus- like virus. It did not show any genomic variation among the strains. Although extensive genomic variation was detected among the avian rotavirus- like virus (RVLV) strain belonging to groups A, D, F and $\mathrm{G}$ of different avian species, but in case of chickens strain that we detected in Gazipur, Dhaka appear to have less variability in genome segments. It was not known whether this reduced variability indicates that these segments are more highly conserved. Additional studies using a greater number of strains obtained from different flocks will be necessary to substantiate this preliminary observation. In the present study it was not investigated whether bacteria, parasites or other viruses were associated as the causal agents of the diarrhoea shedding or diarrhoea induced by rotavirus alone. Thus it remained, unclear whether the rotavirus alone produced diarrhoea in broiler chickens. Further investigations are required in this regard. There is also a scope of research to confirm the zoonotic nature of rotavirus infection. The present study will help to understand the ability to characterize individual virus isolates by genetic analysis of their dsRNA migration patterns of potential importance in epidemiological investigations. The origin of the virus can be traced by characterizing the avian rotaviruses endemic in the avian population. By genotyping viruses from different outbreaks, it will be possible 


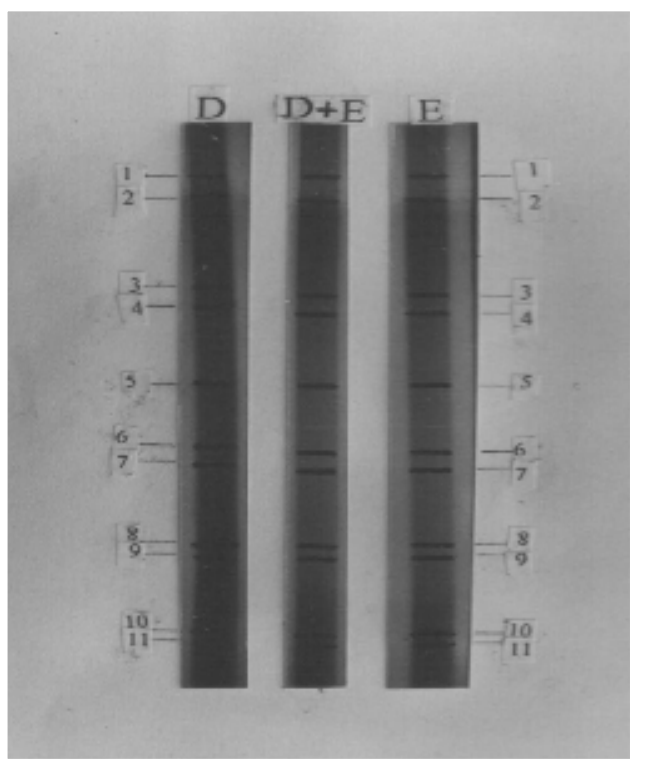

Fig. 2. Co-electrophoresis of avianrotavirus-likevirus electropherotypes in lane ' $D$ ' strain to ' $E$ ' strain [From the extreme left ' $D$ ' strain (avian rotavirus like virus), ' $\mathrm{D}+\mathrm{E}$ ' strain (Mixed electropherotypes of avian rotavirus like virus and ' $E$ ' strain (avian rotavirus like virus)].

to determine whether there has been a transmission of a given agent from one farm to another. It was impossible to determine the significance in dsRNA migration patterns among the isolated strains. Electropherotyping is very useful in the detection of strain variation. It is necessary to analyze a large number of virus strains to obtain detailed epidemiological information and their roles in the pathogenesis of the disease. In addition genetic analysis warrants to confirm the strain that was detected in this study with other avian rotaviruses reported so far.

The continued and expanded application of molecular techniques to the study the rotavirus epidemic will be indispensable in the acquisition of needed epidemiological information to manage outbreaks and to plan and implement control measures for rotavirus enteritis in broiler chickens.

\section{REFERENCES}

1. Espejo RT, Calderon E and Gonzalez N (1977). Distinct reovirus-like agents associated with acute infantile gastroenteritis. Journal of Clinical Microbiology 6: 502-506.

2. Estes MK, Palmer EL and Obijeski JF (1983). Rotaviruses : a review. Current Tropical Microbiology and Immunology 105: 123-184.

3. Hancock K, Gary G and Palmer EL (1983). Adaptation of two avian rotaviruses to mammalian cells and characterization by haemagglutination and RNA electrophoresis. Journal of General Virology 64: 853-861.

4. Kalica AR, Greenberg HB, Espejo RT, Flores J, Wyatt RG, Kapikian AZ and Chenock RM (1981). Distinctive ribonucleic acid patterns of human rotavirus subgroups 1 and 2. Infection and Immunology 33: 958-961.

5. McNulty MS, Allan GM and McFerran JB (1984). Prevalence of antibody to conventional and atypical rotaviruses in chickens. Veterinary Record 114: 219.

6. McNulty MS, Allan GM, Todd D and McFerran JB (1979). Isolation and cell culture propagation of rotaviruses from turkeys and chickens. Archives of Virology 6l: 13-2l.

7. McNulty MS, Allan GM, Todd D, McFerran JB, Mckillop ER, Collins MS and McCracken RM (1980). Isolation of rotaviruses from turkeys and chickens: demonstration of distinct serotypes and RNA electropherotypes. Avian Pathology 9: 363-375 
Rotavirus-like virus in broiler chickens

8. McNulty MS, Allan GM, Todd D, McFerrran JB and McCracken RM (1981). Isolation from chicken of a rotavirus lacking the rotavirus group antigen. Journal of General Virology 55: 405-413.

9. Rodger SM, Bishop RF, Birch C, McLean B and Holmes IH (1981). Molecular epidemiology of human rotaviruses in Melbourne, Australia, from 1973 to 1979, as determined by electrophoresis of genome ribonucleic acid. Journal of Clinical Microbiology 13: 272-278.

10. Rodriguez WZ, Kim HW, Brandt CD, Grandler MK and Parrott RH (1983). Use of electrophoresis of RNA from human rotavirus to establish the identity of strains involved in outbreaks in a Tertiary Care Nursery. Journal of Infectious Diseases 148: 34-40.

11. Saif LJ (1989). Immunodiagnosis of enteric viral infections application of electron microscopy and monoclonal antibodies. Proceedings $38^{\text {th }}$ Western Poultry Disease Conference, Tempe, Ariz. pp. 232-237.

12. Saif LJ, Saif YM and Theil KW (1985). Enteric viruses in diarrhoeic turkey poults. Avian Diseases 29: 798-811.

13. Theil KW and Saif KW (1987). Age related infections with rotavirus, rotavirus like virus and atypical rotavirus in turkey flocks. Journal of Clinical Microbiology 25: 333-337.

14. Theil KW, Reynolds DL and Saif YM (1986). Genomic variation among rotavirus-like viruses detected by polyacrylamide gel electrophoresis. Avian Diseases 30: 829-834.

15. Todd D, McNulty MS and Allan GM (1980). Polyacrylamide gel electrophoresis of avian rotavirus RNA. Journal of General Virology 63: 87-97.

16. Yason CV and Schat KA (1984). Isolation and characterization of avian rotaviruses. Avian Diseases 29: 499-508. 